
andrescatigna@gmail.com) and FRANCISCA HELENA MUNIZ (10) orcid.org/0000-0001-8511-7424) Centro de Educação, Ciências Exatas e Naturais, Departamento de Biologia, Universidade Estadual do Maranhão, São Luís, Maranhão, Brazil

This is an Open Access article, distributed under the terms of the Creative Commons Attribution licence CC BY NC 4.0.

\section{Failing badger protection}

Despite legal protection (Protection of Badgers Act 1992), 105,960 badgers were culled in the UK during 2018-2020 as part of bovine tuberculosis control measures, with licences currently issued to remove up to a further 75,930 badgers commencing 1 June 2021. Nevertheless, developments interfering with badger setts still require licence from Natural England, often necessitating that ecological consultancies mitigate any destructive effects. When a sett impedes intended development, ecological consultancies are contracted to assess the feasibility of replacement with an artificial substitute. There is, however, no legal requirement stipulating that such setts should be adopted, beyond proof the badgers have investigated their new accommodation. In response to our data request of 8 February 2021, Natural England was unable to confirm how many of 1,471 licences granted during 2019-2020 required the construction of artificial setts to replace those closed down or whether any replacement setts subsequently supported breeding.

Surveying ecological consultancies via the British Ecologists Facebook Group during 19 May-15 June 2021, we established that only 10 of 29 respondents were required by Natural England to conduct follow-up monitoring of the artificial setts they constructed; eight additional artificial setts were monitored of the consultant's own volition. Of these 18 setts, breeding was detected at only eight. The success rate is likely to be lower among consultants involved in artificial sett construction who did not respond to our survey. Many artificial setts fail either because the sett is not located within the territorial range of the disenfranchised badger group, as a result of a lack of territorial baitmarking surveying, or because the sett is not sited and constructed in the correct soil substrate to achieve the underground complexity and thermal stability badgers require, especially for breeding success (Tsunoda et al., 2018, Journal of Thermal Biology, 74, 226-233). With culling, traffic accidents and direct persecution already exerting a c. $20 \%$ additional mortality burden on the UK's c. 485,00o badgers (Judge et al., 2017, Scientific Reports, 7, 276), this is an underappreciated issue that needs urgent attention. Every effort should be made to ensure that investments in conservation mitigation are effective; simply demonstrating compliance with minimal criteria does not serve intended welfare or conservation goals.

DANIEL Wood (@ orcid.org/0000-0001-9516-155X) ACD Environmental Ltd, Malmesbury, UK. CHRISTINA BUESCHING (ㄷ orcid.org/0000-0002-4207-5196) Department of Biology, The University of British Columbia, Kelowna, Canada. ChRIS NEWMAN (@ orcid.org/0000-0002-9284-6526, chris. newman@lmh.ox.ac.uk) Wildlife Conservation Research Unit, Department of Zoology, University of Oxford, Oxford, UK

This is an Open Access article, distributed under the terms of the Creative Commons Attribution licence CC BY NC 4.0 .

\section{Habitats of the Endangered Caspian seal identified as Important Marine Mammal Areas}

The Caspian seal Pusa caspica lives only in the landlocked Caspian Sea in western Asia. Since 2008 it has been categorized as Endangered on the IUCN Red List, having declined by $>70 \%$ in the 2oth century, primarily as a result of unsustainable hunting for the species' fur and blubber. On 6 December 2021, the IUCN Task Force on Marine Mammal Protected Areas, a joint task force of the IUCN Species Survival Commission and the World Commission on Protected Areas, announced that three Important Marine Mammal Areas have been identified for the Caspian seal as part of 14 new such areas for the marine mammals of the Black Sea, Turkish Straits and Caspian Sea (see marinemammalhabitat.org/imma-eatlas for further details).

The main threats to Caspian seals stem from human activities, including high rates of seal mortality in fishing gear set for sturgeon poaching, and habitat degradation arising from coastal development. The newly identified Caspian Sea Important Marine Mammal Areas are not protected but are essential habitat for the species. Currently, there are no protected areas designated specifically for the conservation of the Caspian seal that prohibit all forms of economic or industrial activity. It is hoped that this new initiative will stimulate the development of stronger protection for key Caspian seal habitat, including winter breeding ice, migration routes, foraging areas and sites used for haul out on land for resting and moulting. Increasing levels of disturbance have caused Caspian seals to abandon most of their traditional haul-out sites. The formerly large aggregations of the species are now rarely seen.

The Caspian seal was added to the national Red Book of Russia and the List of Rare and Endangered Species of Plants and Animals of Kazakhstan in 2020, making it Red Listed in all five Caspian countries. Following a proposal initiated by the Islamic Republic of Iran, the Caspian seal was added to Appendices I and II of the United Nations Convention on the Conservation of Migratory Species of Wild Animals in 2017. 